Article

\title{
A Novel Evaluation Approach of County-Level City Disaster Resilience and Urban Environmental Cleanliness Based on SDG11 and Deqing County's Situation
}

\author{
Yani Wang ${ }^{1} \mathbb{D}$, Mingyi Du ${ }^{1}$, Lei Zhou ${ }^{1} * \mathbb{C}$, Guoyin Cai ${ }^{1}$ and Yongliang Bai ${ }^{2}$ \\ 1 School of Geomatics and Urban Spatial Informatics, Beijing University of Civil Engineering and Architecture, \\ Beijing 102616, China; 2108160317004@stu.bucea.edu.cn (Y.W.); dumingyi@bucea.edu.cn (M.D.); \\ cgyin@bucea.edu.cn (G.C.) \\ 2 School of Mechanical, Electronic and Control Engineering, Beijing Jiaotong University, Beijing 100044, China; \\ 17116354@bjtu.edu.cn \\ * Correspondence: zhoulei@bucea.edu.cn
}

Received: 19 August 2019; Accepted: 14 October 2019; Published: 16 October 2019

check for updates

\begin{abstract}
City disaster resilience and urban environmental cleanliness are two representative indicators used to assess the safety of human settlements in China's Sustainability Development Goals (SDGs). Traditional research on SDGs mainly concentrated at large-scale spatial level, such as global level or national level. It brings unclear significance to the implementation of SDGs in the county-level. The goal of this paper is to find a new calculation method to apply the index of urban disaster resilience and urban environmental cleanliness to the evaluation of county-level areas. A localization of county-level city disaster resilience and urban environmental cleanliness based on Deqing County's situation was carried out. With quantification and projections of local data, the assessments of city disaster resilience and urban environmental cleanliness have completed. The evaluation showed that city disaster resilience is maintained at a low level, while indicators of urban cleanliness are lower than standards. The prediction of urban per capita environmental impact index based on Grey Time-Series Prediction Model was finished. The forecast showed that the urban per capita impact indicators in the next three years have not exceeded the standard line. The two indicators used to assess the safety of human settlements were consistent with the sustainable development of urban settlement. Partial results of this research were reported as a "county sample" at the first UN Geographic Information Conference held in Deqing in 2018.
\end{abstract}

Keywords: SDG 11; city disaster resilience; urban environmental cleanliness; county-level sample; Deqing County

\section{Introduction}

Natural ecosystems were once considered an inexhaustible resource [1], but with the advent of industrial societies, this traditional cognition has been challenged. Many problems emerged because of industrial expansion and urbanization, especially in developing countries [2]. Thriving urbanization in those countries brought environmental pollution and ecological damage. Consequently, the sustainable development of urban settlement has attracted a lot of attention [3,4]. In 2015, a set of goals-the Sustainable Development Goals (SDGs)—were created (https://undocs.org/ch/A/). RES/70/1) [5], serving as a continuation of the Millennium Development Goals (MDGs). The SDGs are an integral part of the 2030 Agenda, which is a formal declaration adopted by the UN members. The Agenda is a global action plan to seek sustainability in all countries [6], guided by the 17 SDGs, managing all aspects of 
the economy, society and the environment [7-9]. In the 2030 Agenda, human settlements are illustrated as an important indicator of the ability of cities to sustain their development.

With cities now being home to the majority of the global population, their importance for global development is undisputed [10]. "Building cities and human settlements that are inclusive, safe, adaptable and sustainable" (SDG11) is considered the minimum required for sustainable urban development in the 2030 Agenda. The city disaster resilience and urban environmental cleanliness can partially describe SDG11 from two aspects: sudden characterization and persistence characterization. At the same time, to support the Chinese government to complete the SDGs assessment of Deqing smoothly, authors and the relevant scientists who participated in this work discussed many times and gave the following conclusions: to carry out the Single SDG evaluation, the specific target (Targets) were divided into 3 subsets according to the local situation. Indicator 11.5 (disaster resilience) and indicator 11.6 (environmental cleanliness) in SDG11 are divided into one subset for evaluating human settlement security in the published Deqing's Progress Report on Implementing the 2030 Agenda for Sustainable Development [11]. Here are reasons:

(1) With the continuous strengthening of human activities on the environmental impact, the risk of disasters in human settlements is increasing [12]. Due to the urbanization and accumulation of wealth, the occurrence of catastrophes can produce Domino Effect. It turns isolated disaster into catastrophic events, even those last for a short time. Many elements of human settlement construction are affected by natural disasters. Therefore, the 2030 Agenda emphasizes the urgent need for humans to mitigate disaster risks, especially for strengthening the disaster resilience of cities and human settlements. It is necessary for city managers to reconsider the effects of climate change, reasonably reduce disaster risk and build resilience to natural disasters when building human settlements. Through studying on explaining the determinants of disaster resilience, the ability to measure resilience is increasingly being identified as a key step toward disaster risk reduction [13].

(2) Improving environmental quality is critical to accelerate the process of urban resilience. It has also become a mandatory goal to implement the 2030 Agenda for the Chinese government. By optimizing the management of natural resources, human can reduce the possibility of natural disasters and the possibility of large-scale outbreaks of environmental pollution caused by disasters. The current high consumption economic model will bring a lot of pressure to the environmental carrying capacity. The positive impact of environmental factors in "2030 Agenda" needs to be used to address the challenges posed by climate change, environmental pollution and waste management [14-16].

At present, the construction of indicator system and proposal of evaluation method for SDGs, included SDG11 "urban sustainable development", are mostly based on the study at national level $[10,17,18]$. There is little research on how to conduct assessments of relevant indicators for SDG 11 at county level. Assessing city disaster resilience and urban environmental cleanliness based on SDG11 is a work that needs to be implemented for most cities in the world to carry out urban sustainable development. In order to complete the evaluation of city disaster resilience and urban environmental cleanliness in Deqing County, the traditional research on different spatial scales of disasters and the environment is used as a reference $[19,20]$. At present, a lot of research has been accumulated in large spatial scale, like global scale or national scale [21-23]. Actually, their research often concentrated on major urban agglomerations and some major cities [24-27] because of rich data of those large spatial scale regions.

In addition to a functional institutional framework, the existence of concrete action plans and the coherence of sustainable development policies are essential to achieving SDG11 [28]. Although some researchers have made some progress in the evaluation index system of SDG11, there are still some defects on the city disaster resilience and urban environmental cleanliness of human settlements. Indicator availability, spatial scale, and disaggregation are addressed firstly when implementing 
sustainable development at county level. The traditional research on SDG11 related indicators focuses on the analysis of existing data. However, with persistent characteristics of sustainability indicators, some indicators can be analyzed from the predictive perspective to enrich the research content of sustainable development.

In order to better apply SDGs to China's assessment, it is necessary to address the impact of data shortages and indicator applicability on city disaster resilience and urban environmental cleanliness. Aiming at the actual situation of Deqing County in this study area, a new county-level urban resilience and urban environmental cleanliness evaluation method was proposed. First, a method for localization of indicators was presented to select indicators for county-level disaster and environment in SDG 11 for county-level assessments. Second, to enrich the reporting on SDG indicators, in this paper, the Grey Time-Series Prediction Model was used to predict urban per capita environmental impact. To verify the feasibility of proposed approach, the statistical data of Deqing County have collected as material for evaluation of county-level sustainable development.

The goal of this paper is to find a new calculation method to apply the index of urban disaster resilience and urban environmental cleanliness to the evaluation of county-level areas. The paper is organized as follows: after this introduction that outlines the main research question of this work and regards city disaster resilience and urban environmental cleanliness as more specific objectives for evaluation in Section 1. The study area and data sources used for the analysis and the methodology for calculating city disaster resilience and urban environmental cleanliness of human settlements are discussed in Section 2. The method part included the localization of indicators for the research area and the calculation method for index quantification. A model for prediction, Grey Time-Series Prediction Model, is also proposed for the next research. The two indexes are evaluated quantitatively in Section 3. At the same time, aiming at the inadequacy of urban environmental cleanliness data, Grey Time-Series Prediction Model was used to forecast and expand the urban environmental cleanliness data. More information that is relevant and working plans were discussed for a richer discussion in the Section 4, and conclusions are drawn in the Section 5.

\section{Materials and Methods}

\subsection{County Situation Introduction}

Deqing County is located in the north of Zhejiang Province, China. Its geographical position is shown in Figure 1. The total area of Deqing is $937.92 \mathrm{~km}^{2}$ and the registered population is 430,000 . With many mountains in the west, the relief amplitude in Deqing County is very high. It belongs to the subtropical wet monsoon climate with abundant heat and rich precipitation. The change of wind direction has distinct characteristics in different seasons [29].

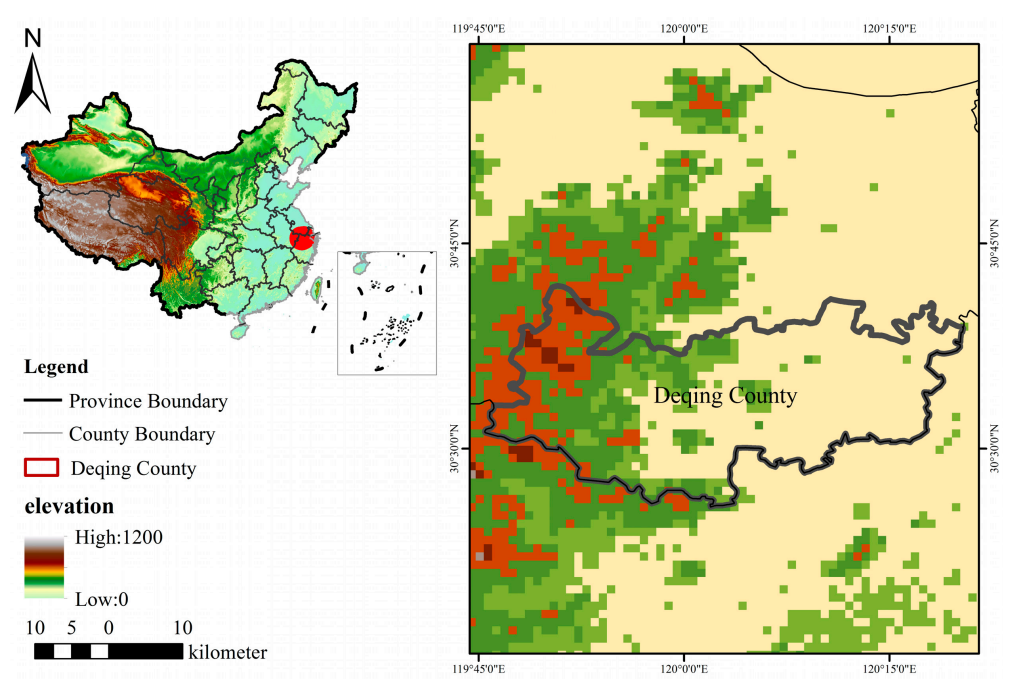

Figure 1. Geographical distribution map of Deqing County. 
Deqing County's sustainable development and green development practices have achieved outstanding results, but making cities and human settlements inclusive, safe, resilient and sustainable remains the most pressing issue. In particular, disaster resilience and environmental cleanliness, which have a direct impact on human survival, should be taken seriously in the process of sustainable urban development. Deqing County is an integral part of Hangzhou metropolitan area, which is located in the center of Yangtze River Delta urban agglomeration. It is affected by the concentrated emission of various atmospheric pollutants from surrounding cities, the urban pollution prevention planning of Deqing County is facing challenges [30]. Deqing County has implemented a management model of urban construction with local characteristics in order to promote sustainable development.

\subsection{Data Collection}

The fundamental step of this paper was to conduct a survey on the SDGs, collecting data and gathering information from Deqing County. With the support of Deqing County Government, disaster loss data (from 2011 to 2017), solid waste collection and utilization data (from 2014 to 2017), fine particulate matter annual concentration data (from 2014 to 2017) and population data (from 2014 to 2017) were collected as the basic database for this study. These data will be used to calculate indicators of city disaster resilience and urban environmental cleanliness.

\subsection{Methodology}

\subsubsection{Localization of Indicators}

In the United Nations World Geographic Information held in 2018, the Progress report for Deqing's Progress Report on Implementing the 2030 Agenda for Sustainable Development (2017) pointed out that Indicator 11.5 (City disaster resilience) and Indicator 11.6(Urban environmental cleanliness) from the SDGs are commonly used to evaluate settlement security. To assess the security and sustainability of human settlements, indicators 11.5 and 11.6 were selected as study indicators based on the content of the report.

Regular missing of data and estimates makes it more difficult to assess the indicators, meanwhile, many SDG targets cannot be properly translated into measurable indicators due to the conceptual complexity [31]. Based on the two reasons above, the empirically assess interlinkages between the SDGs in a comprehensive manner are not always available. In this paper, the localization of indicators should be applied to the evaluation of indicators in Deqing County. The localization of indicators refers to the formation of a set of indicators with local characteristics by retaining or modifying SDGs, on the basis of fully understanding the 2030 Agenda and combining with the actual situation of Deqing County. Localization of indicators is shown in Table 1.

City disaster resilience mainly reflects the impact of regional disasters on human settlement security and urban construction [13]. This impact can be quantified by calculating Indicator 11.5.1 and Indicator 11.5.2. The content of Indicator 11.5.2 has been modified to enhance the applicability and comparability of the indicator in Deqing County. Urban environmental cleanliness mainly indicates the ability of the regional environmental system to withstand various types of pollutants produced by economic and social activities. In view of the functional orientation of cities and human settlements, Indicator 11.6.1 and Indicator 11.6.2 were used to comprehensively reflect the sustainability of urban environmental cleanliness. Also, the evaluation of urban solid waste in Indicator 11.6.1 was divided into two parts: living solid waste and industrial solid waste, making the evaluation content more specific. According to the Announcement on the status of Ecological Environment in China issued by the Ministry of Ecological Environment of the People's Republic of China, $\mathrm{PM}_{2.5}$ and $\mathrm{PM}_{10}$ are the main pollutants in most parts of China. Combined with the air pollution in the study area, the pollutants represented by $\mathrm{PM}_{2.5}$ and $\mathrm{PM}_{10}$ will be used as the target for the calculation of annual mean levels of fine particulate matter in Indicator 11.6.2. 
Table 1. United Nations SDGs and Localization of indicators.

\begin{tabular}{|c|c|c|}
\hline \multicolumn{3}{|c|}{ SDG 11: Make cities and human settlements inclusive, safe, resilient and sustainable [32] } \\
\hline Target $^{a}$ & $\begin{array}{l}\text { 11.5: By 2030, significantly reduce the number of } \\
\text { deaths and the number of people affected and } \\
\text { substantially decrease the direct economic losses } \\
\text { relative to global gross domestic product caused } \\
\text { by disasters, including water-related disasters, } \\
\text { with a focus on protecting the poor and people in } \\
\text { vulnerable situations. }\end{array}$ & $\begin{array}{l}\text { 11.6: By } 2030 \text {, reduce the adverse per } \\
\text { capita environmental impact of cities, } \\
\text { including by paying special attention to } \\
\text { air quality and municipal and other } \\
\text { waste management. }\end{array}$ \\
\hline \multirow[t]{2}{*}{ Indicator $^{b}$} & $\begin{array}{l}\text { 11.5.1: Number of deaths, missing persons and } \\
\text { persons affected by disaster per } 100,000 \text { people }\end{array}$ & $\begin{array}{l}\text { 11.6.1: Proportion of urban solid waste } \\
\text { regularly collected and with adequate } \\
\text { final discharge out of total urban solid } \\
\text { waste generated, by cities }\end{array}$ \\
\hline & $\begin{array}{l}\text { 11.5.2: Direct disaster economic loss in relation to } \\
\text { global GDP, including disaster damage to critical } \\
\text { infrastructure and disruption of basic services }\end{array}$ & $\begin{array}{l}\text { 11.6.2: Annual mean levels of fine } \\
\text { particulate matter (e.g. } \mathrm{PM}_{2.5} \text { and } \mathrm{PM}_{10} \text { ) } \\
\text { in cities (population weighted) }\end{array}$ \\
\hline \multirow[t]{2}{*}{$\begin{array}{l}\text { Indicator } \\
\text { localization }^{c}\end{array}$} & $\begin{array}{l}\text { 11.5.1: Number of deaths, missing persons and } \\
\text { persons affected by disaster per } 100,000 \text { people }\end{array}$ & $\begin{array}{l}\text { 11.6.1: Proportion of urban solid waste } \\
\text { (living solid waste and industrial solid } \\
\text { waste) regularly collected and with } \\
\text { adequate final discharge out of total } \\
\text { urban solid waste generated, by cities }\end{array}$ \\
\hline & $\begin{array}{l}\text { 11.5.2: Direct disaster economic loss in relation to } \\
\text { global GDP, including disaster damage to critical } \\
\text { infrastructure and disruption of basic services }\end{array}$ & $\begin{array}{l}\text { 11.6.2: Annual mean levels of fine } \\
\text { particulate matter (e.g. } \mathrm{PM}_{2.5} \text { and } \mathrm{PM}_{10} \text { ) } \\
\text { in cities (population weighted) }\end{array}$ \\
\hline \multirow{2}{*}{ Description $^{\mathrm{d}}$} & 11.5.1: Adopted the original indicator & 11.6.1: Revised the original indicator \\
\hline & 11.5.2: Revised the original indicator & 11.6.2: Adopted the original indicator \\
\hline
\end{tabular}

\subsubsection{Calculation of Localized Indicators}

While some of these indicators are easy to define and measure, roughly half of them lack acceptable country coverage, cross-regional comparability, or agreed-upon methodologies for measurement. Based on the localization innovation of indicators, the calculation formulas of indicators 11.5.1, indicators 11.5.2, indicators 11.6.1 and indicators 11.6 .2 were innovatively proposed. The calculation of the formulas can complete the evaluation of city disaster resilience and urban environmental cleanliness in Deqing County, and to make the evaluation results comparable.

The number of deaths, missing persons and persons affected by disaster per 100,000 people can be calculated. The calculation results of Equation (1) were used as the basis for evaluation of indicator 11.5.1.:

$$
F(X)=\sum_{i=1}^{n} \frac{X_{i}^{\alpha}}{\left(P_{i} / W\right)}(i \in R, i=1,2, \cdots \mathrm{n})
$$

Among them, $F(X)$ has three values per year, representing the number of deaths (direct deaths during or after disasters), missing persons (missing people due to disasters) and people affected by disasters (people affected by disasters) per 100,000 people; $X$ stands for the statistical number of deaths caused by disasters of all kinds; $\alpha$ represents the types of disasters (such as snowstorms, floods, earthquakes, droughts, etc.); $i$ represents the year; $P_{\mathrm{i}} / W$ represents the weight of population; $P i$ represents the total population of different years; $W$ is 100,000 people.

The relationship between the economic loss of disasters and GDP in the whole county is calculated by proportion. The evaluation of indicator 11.5.2 depended on the calculation result of Equation (2): 


$$
P(i)=\frac{\sum_{j=1}^{\mathrm{n}} \operatorname{Cost}_{\text {disaster }}(i, j)}{G D P_{i}}(i \in R, \mathrm{j} \in R, i=1,2, \cdots m)
$$

where $E(i)$ represents the proportion of disaster economic loss to GDP in the whole county; Cost $_{\text {disaster }}$ represents the economic losses caused by disasters; $(i, j)$ represents the $j$ disaster that occurred in year $i$.

Environmental cleanliness indicators for calculating the comprehensive utilization rate of solid wastes are described by Equation (3):

$$
S \mathrm{w}=\sum_{P=1}^{n} \frac{\operatorname{Re}_{(p)}}{\operatorname{Tot}_{(p)}} * 100 \%
$$

where $S w$ represents solid waste recycling share; Re represents the volume of recycled share; Tot represents total collected waste; $t$ represents the villages and streets within the study area; $S w$ is subdivided into industrial solid waste and domestic solid waste for statistics and calculation.

The formula for calculating the per capita environmental impact is given by Equation (4):

$$
\mathrm{A}(\mathrm{X})=\sum_{i=1}^{n} \frac{A_{i}^{*}(\mathrm{X})}{\left(P_{i} / W\right)}
$$

where $A(X)$ represents the annual average concentration of $\mathrm{PM}_{10}$ and $\mathrm{PM}_{2.5} ; A^{*}(X)$ represents the annual average concentration of $\mathrm{PM}_{10}$ and $\mathrm{PM}_{2.5}$ per year; $i$ represents year; $P_{\mathrm{i}} / W$ represents population weight (total population $/ 100,000)$.

\subsubsection{Grey Time-Series Prediction Model}

Since 2013, the Chinese government has added $\mathrm{PM}_{2.5}$ and $\mathrm{PM}_{10}$ concentration monitoring to air quality monitoring. It means the limitations and shortages of the statistical data used to research time series variation in $\mathrm{PM}_{2.5}$ and $\mathrm{PM}_{10}$ concentrations need to consider. The relationship between environmental indicators and influencing factors is very complicated, and it maintains a certain regular change over a long period of time. The calculation and evaluation of indicators require sufficient data, and the extra predicted data as a supplement to the results of per capita environmental impact through small samples. With existing data and forecast data as the basis for evaluation of indicators, a more accurate and abundant expression of indicators can be obtained. The Grey Time-Series Prediction Model is better to resolve the poor information questions in the process of predicting, weakens of the randomness of historical data disturbance factors and reveals the inherent and regularity of the history time series of chaos [33]. It can realize an accurate description and understanding of the real world by processing mining the information of existing data [34,35]. The Grey Time-Series Prediction Model has been used for hydrology time series prediction, meteorological sequence prediction and forecast of greenhouse gas emissions [36-38]. The Grey Time-Series Prediction Model was used to predict the trends of the Indicator 11.6.2, which represent the per capita environmental impact in the next few years. The related calculations are shown in Equations (5)-(7).

(1) Sample $X^{(0)}$ of population and environmental pollutant concentration has $\mathrm{N}$ available ata: $X^{(0)}=\left\{X^{(0)}(1), X^{(0)}(2), \ldots, X^{(0)}(n)\right\}$, a new sequence $X^{(1)}=\left\{X^{(1)}(1), X^{(1)}(2), \ldots, X^{(1)}(n)\right\}$ can be generated by accumulation [39]. The corresponding differential equation of GM $(1,1)$ is:

$$
\frac{d X^{(1)}}{d t}+a X^{(1)}=\mu
$$

Among them: $\alpha$ is called development gray number; $\mu$ is called endogenous control gray number. 
(2) Let $\hat{\alpha}$ be the parameter vector to be estimated: $\hat{\alpha}=\left(\frac{a}{\mu}\right)$, which can be solved by the least squares method. The solution is:

$$
\hat{\alpha}=\left(B^{T} B\right)^{-1} B^{T} Y_{n}
$$

By solving the differential equation, the prediction model of per capita environmental impact can be obtained:

$$
\hat{X}^{(1)}(k+1)=\left[X^{(0)}(1)-\frac{\mu}{a}\right] e^{-a k}+\frac{\mu}{a}, k=0,1,2 \ldots, n
$$

\section{Results}

\subsection{Evaluation Results}

According to Indicator 11.5.1 on "Disaster impact", city disasters consist of two factors: meteorological disasters (such as heavy rain, drought, frost and low temperature, etc.) and geological disasters (landslides, debris flows, ground collapse, etc.). The deaths, missing persons and persons affected by disaster are the main evaluation factors for disaster assessment. The meteorological disasters in Deqing County are dominated by typhoons and blizzards, thus the result of disaster indicators is only applied for meteorological disasters. Based on Equation (1), the content of Indicator 11.5.1 was quantified. The results are shown in Figure 2.

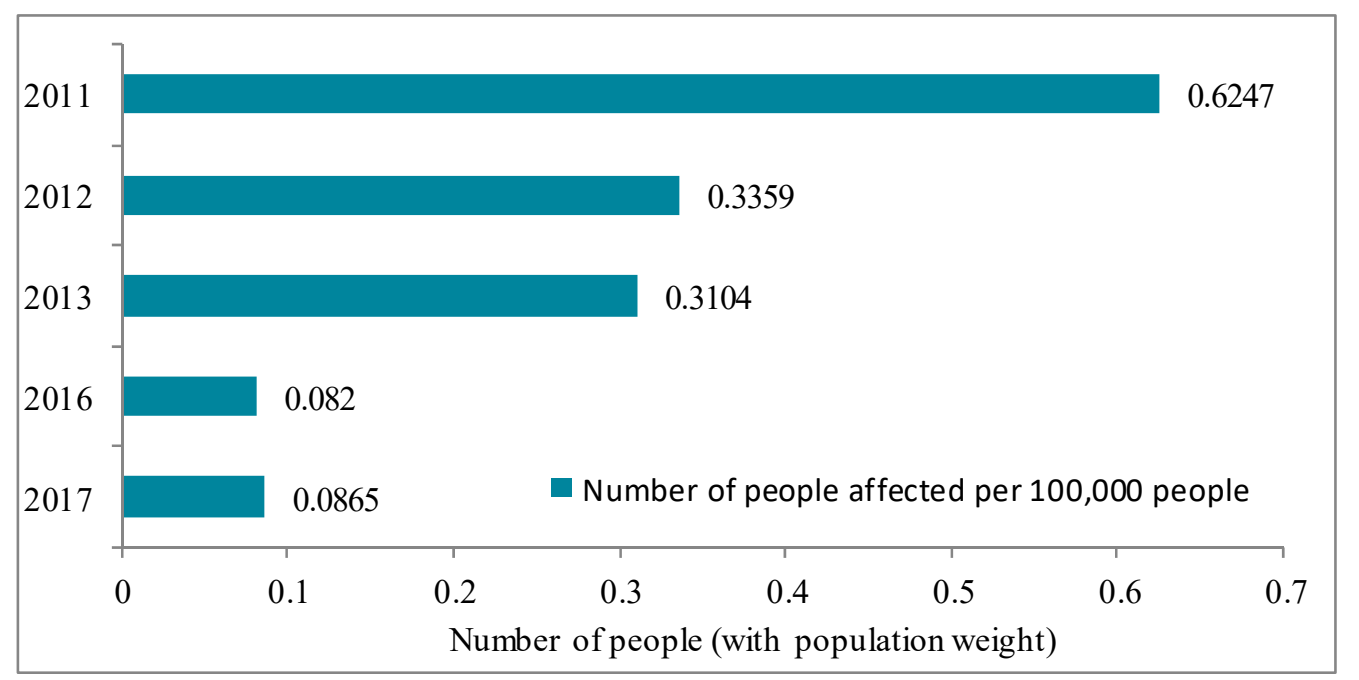

Figure 2. Number of people death, missing and affected by disasters (adding population weight). There are no deaths or missing persons as a result of the disaster, the two calculations are not shown in the figure.

For indicator 11.5.2 on "economic loss", the quantitative results of the economic impact by disasters in Deqing County are shown in Table 2. Except for individual years, the economic losses caused by disasters make obvious effects on the economic development of Deqing County.

Table 2. Ratio of economic losses caused by disasters.

\begin{tabular}{cc}
\hline Year & Percentage of Economic Losses Caused by Disasters \\
\hline 2011 & $0.92 \%$ \\
2012 & $0.22 \%$ \\
2013 & $0.27 \%$ \\
2016 & $2.69 \%$ \\
2017 & $0.74 \%$ \\
\hline
\end{tabular}

Deqing County is a place where the frequency of the disasters is low and the disaster category is relatively singular. In order to make the evaluation results more targeted, the quantitative results based 
on index 11.5 of Deqing County are briefly explained. With the abovementioned results of Indicator 11.5.1 and Indicator 11.5.2, the meteorological disasters stay at a low level. Therefore, considering that the disaster has less influence on the sustainable development of Deqing County, human security settlements can be built in Deqing County. The results can be a reference for Deqing County to gradually realize the management from subjective to scientific in disaster reduction.

For indicator 11.6.1 on "solid waste", the comprehensive utilization rate of solid waste was calculated according to Equation (2) from the obtained data. In the United Nations World Geographic Information held in 2018, the Progress report for Deqing's Progress Report on Implementing the 2030 Agenda for Sustainable Development (2017) pointed out that the utilization rate of solid waste in China is $69.3 \%$. The calculation results showed that the living solid waste in Deqing County maintains a comprehensive utilization rate of $100 \%$ all the year. The comprehensive utilization rate of industrial solid waste exceeds $93 \%$, which is much higher than the national average in China. This is due to the environmental protection concept of Deqing County changed from "treatment after pollution" to "environmental protection priority". The concept holds that people should give prevention and treatment to the rapid development of solid waste pollution in urbanization to reach advanced standards. It meets the basic requirement of growing ecological needs and human settlement security. As stated above, the recycling share of solid waste is confirmed to meet the standard for sustainable development of urban environmental cleanliness in Deqing County.

For indicator 11.6.2 on "air quality", per capita fine particulate matter $\left(\mathrm{PM}_{2.5}\right.$ and $\left.\mathrm{PM}_{10}\right)$ concentration is an effective method to measure the air quality under the condition of different population in various cities. This issue is described by the metadata file issued by the United Nations to guide the implementation of SDGs. By adding population weight, the calculated results of indicator can be compared quantitatively between different regions. The annual average data of fine particle concentration $\left(\mathrm{PM}_{2.5}\right.$ and $\left.\mathrm{PM}_{10}\right)$ and population data were provided by the Deqing County Government. The data was used for the calculation of indicator 11.6.2. Based on Equation (3), the per capita fine particulate matter $\left(\mathrm{PM}_{2.5}\right.$ and $\left.\mathrm{PM}_{10}\right)$ concentration from 2014 to 2017 in Deqing County was calculated. The calculation results are shown in Table 3.

Table 3. Annual average of $\mathrm{PM}_{10}$ and $\mathrm{PM}_{2.5}$ (with population weight).

\begin{tabular}{ccc}
\hline Year & $\mathbf{P M}_{\mathbf{1 0}}$ (with Population Weight) $/\left(\mu \mathrm{g} / \mathbf{m}^{3}\right)$ & $\mathbf{P M}_{\mathbf{2 . 5}}$ (with Population Weight) $/\left(\mu \mathrm{g} / \mathbf{m}^{3}\right)$ \\
\hline 2014 & 14.87 & 23.32 \\
2015 & 12.24 & 19.66 \\
2016 & 9.74 & 15.46 \\
2017 & 9.29 & 14.32 \\
\hline
\end{tabular}

With reference to the evaluation criteria for per capita environmental impact in the SDGs Index and Reference Standard (evaluation criteria for some SDGs), the per capita $\mathrm{PM}_{2.5}$ concentration has reached the goal of sustainable development in 2017 (per capita $\mathrm{PM}_{2.5}$ concentration) $\leq 10$ ). Referring to the formulation of $\mathrm{PM}_{2.5}\left(<35 \mu \mathrm{g} / \mathrm{m}^{3}\right)$ and $\mathrm{PM}_{10}\left(<70 \mu \mathrm{g} / \mathrm{m}^{3}\right)$ concentrations in the Chinese government's environmental air quality standards (without population weight), when the per capita $\mathrm{PM}_{10}$ concentration is less than $20 \mu \mathrm{g} / \mathrm{m}^{3}$, the per capita $\mathrm{PM}_{10}$ concentration meets the sustainable development standards. According to the results of Table 3, per capita $\mathrm{PM}_{10}$ concentration has reached the standard (per capita $\mathrm{PM}_{10}$ concentration) $\leq 20$ ) in 2015, and the calculated value from 2015 to 2017 has maintained a downward trend.

Combined with the evaluation results of Indicators 11.6.1 and Indicators 11.6.2, the environmental cleanliness of Deqing County has reached the basic requirements for building a human settlement.

\subsection{Prediction Results of Urban per Capita Environmental Impact}

To better promote the realization of SDGs, China has released its national plan for the implementation of the 2030 Agenda for Sustainable Development (referred to as the "China plan"). 
As the stage goal of implementing urban environmental cleaning, "by 2020, the number of days of heavy pollution in cities will be reduced by $25 \% "$, which has been put forward in China plan. In addition, the studies on $\mathrm{PM}_{2.5}$ and $\mathrm{PM}_{10}$ concentration are based on the real-time data observed by air quality monitoring stations established at national and local levels, and no related trend prediction research has been carried out. In this paper, fine particulate matter $\left(\mathrm{PM}_{2.5}\right.$ and $\left.\mathrm{PM}_{10}\right)$ concentration and population in Deqing County from 2014 to 2017 are used as input data of Grey Time-Series Prediction Model to predict the changes of $\mathrm{PM}_{2.5}, \mathrm{PM}_{10}$ and population from 2018 to 2020. Using the predicted value, the results of urban per capita environmental impact in the next few years can be calculated. The forecast results can be used as part of the evaluation basis for judging whether the goal of "reducing urban heavy pollution days by $25 \%$ in 2020" can be successfully achieved, and also can provide some decision and data support for forward-looking policy making and schedule planning. The results are shown in Figure 3.

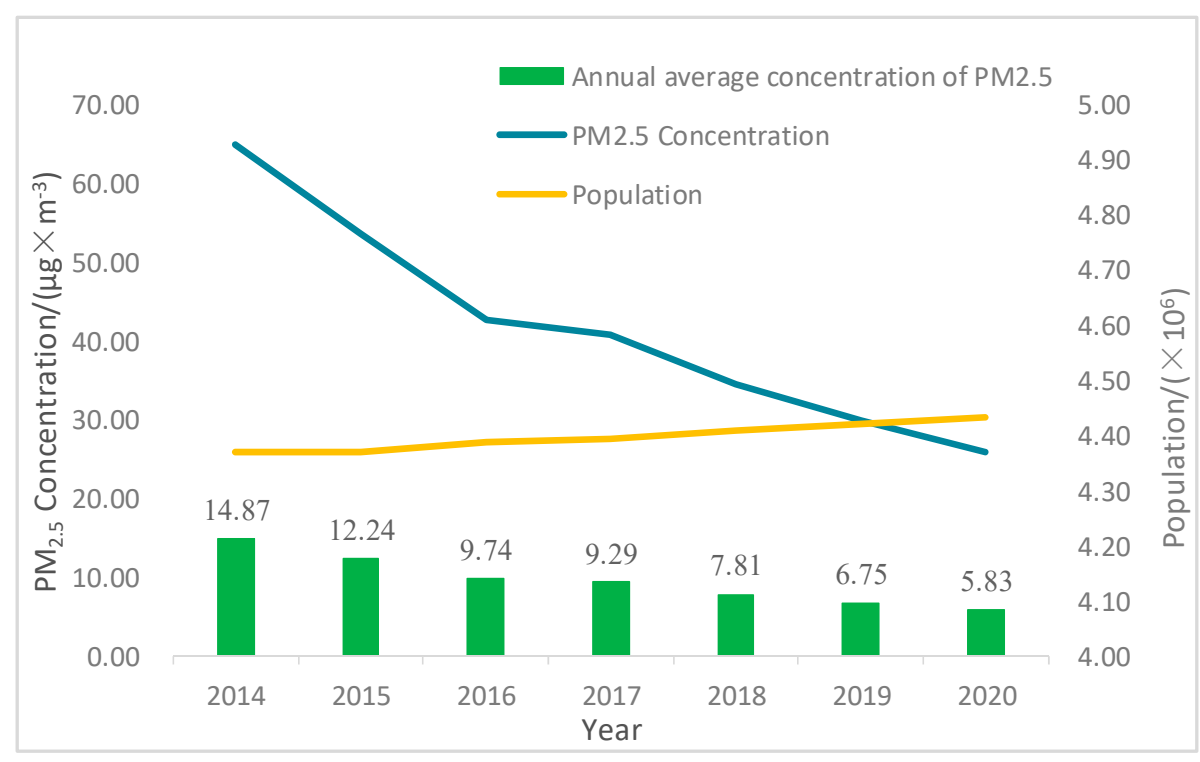

(a) $\mathrm{PM}_{2.5}$ concentration and population forecast.

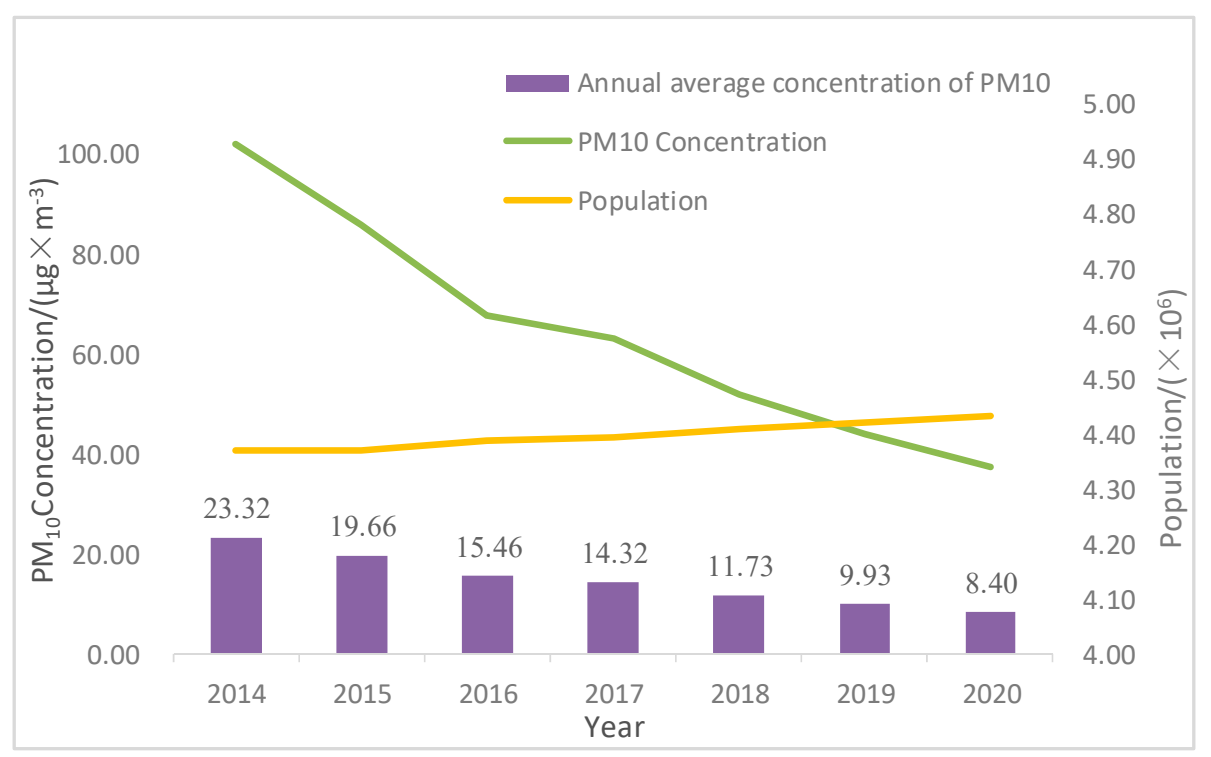

(b) PM10 concentration and population forecast.

Figure 3. Prediction of $\mathrm{PM}_{2.5}$ and $\mathrm{PM}_{10}$ per capita. 
The $\mathrm{PM}_{2.5}$ concentration (Figure 3a) and $\mathrm{PM}_{10}$ concentration (Figure 3b) from 2018 to 2020 were predicted. Figure 3 shows some interesting information: (1) Both indicators are decreasing year by year; (2) By the end of 2020, $\mathrm{PM}_{2.5}$ concentration and $\mathrm{PM}_{10}$ concentration will have decreased by more than $50 \%$ compared with 2014. As two representative indicators, $\mathrm{PM}_{2.5}$ and $\mathrm{PM}_{10}$ directly affect the air quality. The decline in the concentration of $\mathrm{PM}_{2.5}$ and $\mathrm{PM}_{10}$ can directly lead to a downward trend in the number of heavy pollution days, thus achieving the goal of China plan will be achieved by 2030 . Meanwhile, based on the results of $\mathrm{PM}_{2.5}$ and $\mathrm{PM}_{10}$ concentration prediction, the annual per capita $\mathrm{PM}_{2.5}$ concentration and annual per capita $\mathrm{PM}_{10}$ concentration were calculated. The results unfolded that the per capita $\mathrm{PM}_{2.5}$ concentration and the per capita $\mathrm{PM}_{10}$ concentration presented a trend of decreasing year by year. The prediction results are verified by the population data and fine particle concentration data of Deqing County in 2018, and the similarity between the calculated results and the predicted results is more than $75 \%$. The predicted results can be used to describe the changing trend of per capita fine particulate matter $\left(\mathrm{PM}_{2.5}\right.$ and $\left.\mathrm{PM}_{10}\right)$ concentration in Deqing County from 2018 to 2020. Per capita fine particulate matter $\left(\mathrm{PM}_{2.5}\right.$ and $\left.\mathrm{PM}_{10}\right)$ concentration can be seen as an indicator that can meet the sustainable development of human settlements.

\section{Discussion}

The key to sustainable development is carrying out a comprehensive analysis of the economy, the society and the environment. However, the city disaster resilience and urban environmental cleanliness which have been completed can only partially describe SDG11 from two aspects: sudden characterization and persistence characterization. It is not enough to build a complete evaluation system of urban sustainable development. At the same time, in order to make the evaluation system generally applicable to different cities in China, the evaluation of sustainable development in different regions will be carried out. The complete SDGs consist of 17 sustainable development goals and 169 targets, and the relationship and integration of the indicators are very important for the implementation of the indicators. The purpose of the United Nations Development Summit is to achieve economic, social and environmental dimensions of sustainable development more integrated by 2030. In response to this purpose, and achieve a comprehensive description of sustainable development, the intrinsic relevance and coordination of 17 SDG indicators need to be analyzed in the next step of work. For example, an in-depth analysis of SDG1, SDG3, SDG4, and SDG5 with the same social indicators as SDG11 is carried out. Furthermore, through the integration and analysis of the relevant SDG indicators, the research based on city disaster resilience and urban environmental cleanliness will be further deepened, and a more complete, systematic and targeted sustainable development construction scheme will be obtained.

\section{Conclusions}

Based on our deep analysis of SDG11, a conclusion can be found that city disaster resilience and urban environmental cleanliness are two important factors in assessing the safety of cities and human settlements, and they play a primary and necessary part of the sustainable development of cities. The SDG holds promise to translate aspirational targets into equally impressive actions. However, if the connection will be made between goals and action in cities, better detailed interpretation of the indicators will be essential.

A primary issue emerging from this paper involves how to implement the indicator localization of city disaster resilience and urban environmental cleanliness in China. On the premise of satisfying existing requirements, more targeted measures should be used to link these indicators with local realities. In this article, a concrete example was provided to verify the applicability of localized indicators of city disaster resilience and urban environmental cleanliness in China. Deqing County, as a research area, is a county-level region that developed rapidly in recent years. The implementation of sustainability assessments in such a region is very representative in China.

Interpretation of Indicator evaluation from the Target 11.5 show that the city disaster resilience of Deqing County remains at a high level. Therefore, Deqing County's city disaster resistance was used as 
a basis for assessing the sustainable development of human settlements. As for Target 11.6, prominent advantages and positive merits were found in the inclusion of solid waste and air quality. In Deqing County, the living solid waste maintains a comprehensive utilization rate of $100 \%$ all the year, and the comprehensive utilization rate of industrial solid waste exceeds $93 \%$, which is much higher than the national average in China. The per capita $\mathrm{PM}_{2.5}$ concentration decreased to $9.29 \mu \mathrm{g} / \mathrm{m}^{3}$, and the per capita $\mathrm{PM}_{10}$ concentration decreased to $14.32 \mu \mathrm{g} / \mathrm{m}^{3}$, which all met the criteria for sustainable development. To further characterize the per capita environmental impact, the concentration of fine particulate matter $\left(\mathrm{PM}_{2.5}\right.$ and $\left.\mathrm{PM}_{10}\right)$ and the population in the next three years were predicted. Based on measured and predicted data, the per capita concentration of $\mathrm{PM}_{2.5}$ and $\mathrm{PM}_{10}$ were calculated which showed the trend of decreasing year by year.

Our research concludes that localization of indicators and local data can support researchers in assessing city disaster resilience and urban environmental cleanliness in Deqing County. The findings of our study can provide a theoretical basis for sustainable development planning and environmental policy formulation in Deqing County. Also, it can provide county-level samples for "2030 Agenda for Sustainable Development", contribute to further research of sustainable development.

Author Contributions: Conceptualization, formal analysis, L.Z. and Y.W.; investigation, methodology, Y.W. and G.C.; data curation, writing—original draft preparation, Y.W.; writing-review and editing, L.Z. and Y.B.; project administration, L.Z.; funding acquisition, M.D. and L.Z.

Funding: This research was funded by General Project of Science and Technology Plan of Beijing Education Commission (KM201810016014), the National Natural Science Foundation (NSFC) (Key Project \# 41930650), the National Key Research and Development Program of China (2018YFC0706003, 2017YFC1502402), Beijing Advanced Innovation Center for Future Urban Design (UDC2018030611).

Conflicts of Interest: The authors declare no conflict of interest.

\section{References}

1. Hou, X.; Liu, J.; Zhang, D. Regional sustainable development: The relationship between natural capital utilization and economic development. Sustain. Dev. 2019, 27, 183-195. [CrossRef]

2. Zinkernagel, R.; Evans, J.; Neij, L. Applying the SDGs to Cities: Business as Usual or a New Dawn? Sustainability 2018, 10, 3201. [CrossRef]

3. Orzes, G.; Moretto, A.M.; Ebrahimpour, M.; Sartor, M.; Moro, M.; Rossi, M. United Nations Global Compact: Literature review and theory-based research agenda. J. Clean. Prod. 2018, 177, 633-654. [CrossRef]

4. Salvia, A.L.; Leal Filho, W.; Brandli, L.L.; Griebeler, J.S. Assessing research trends related to Sustainable Development Goals: Local and global issues. J. Clean. Prod. 2019, 208, 841-849. [CrossRef]

5. Jacob, A. Mind the Gap: Analyzing the Impact of Data Gap in Millennium Development Goals' (MDGs) Indicators on the Progress toward MDGs. World Dev. 2017, 93, 260-278. [CrossRef]

6. Vandemoortele, J. From simple-minded MDGs to muddle-headed SDGs. Dev. Stud. Res. 2018, 5, 83-89. [CrossRef]

7. Mbah, P.O.; Nzeadibe, T.C. Inclusive municipal solid waste management policy in Nigeria: Engaging the informal economy in post-2015 development agenda. Local Environ. 2017, 22, 203-224. [CrossRef]

8. Diaz-Sarachaga, J.M.; Jato-Espino, D.; Castro-Fresno, D. Is the Sustainable Development Goals (SDG) index an adequate framework to measure the progress of the 2030 Agenda? Sustain. Dev. 2018, 26, 663-671. [CrossRef]

9. Horn, P.; Grugel, J. The SDGs in middle-income countries: Setting or serving domestic development agendas? Evidence from Ecuador. World Dev. 2018, 109, 73-84. [CrossRef]

10. Ulbrich, P.; Porto de Albuquerque, J.; Coaffee, J. The Impact of Urban Inequalities on Monitoring Progress towards the Sustainable Development Goals: Methodological Considerations. ISPRS Int. J. Geo-Inf. 2018, 8, 6. [CrossRef]

11. Jun Chen, Z.L. Chinese pilot project tracks progress towards SDGs. Nature 2018, 563, 184. [CrossRef]

12. Folke, C.; Kofinas, G.P.; Chapin, F.S. Principles of Ecosystem Stewardship; Springer: Berlin/Heidelberg, Germany, 2009.

13. Burton, C.G. A Validation of Metrics for Community Resilience to Natural Hazards and Disasters Using the Recovery from Hurricane Katrina as a Case Study. Ann. Assoc. Am. Geogr. 2014, 105, 67-86. [CrossRef] 
14. Zhang, H.; Wang, Z.; Zhang, W. Exploring spatiotemporal patterns of PM2.5 in China based on ground-level observations for 190 cities. Environ. Pollut 2016, 216, 559-567. [CrossRef]

15. Bari, M.A.; Kindzierski, W.B. Characteristics of air quality and sources affecting fine particulate matter (PM2.5) levels in the City of Red Deer, Canada. Environ. Pollut 2017, 221, 367-376. [CrossRef]

16. Shahsavari, A.; Akbari, M. Potential of solar energy in developing countries for reducing energy-related emissions. Renew. Sustain. Energy Rev. 2018, 90, 275-291. [CrossRef]

17. Imamura, K.; Takano, K.T.; Mori, N.; Nakashizuka, T.; Managi, S. Attitudes toward disaster-prevention risk in Japanese coastal areas: Analysis of civil preference. Nat. Hazards 2016, 82, 209-226. [CrossRef]

18. Koch, F.; Krellenberg, K. How to Contextualize SDG 11? Looking at Indicators for Sustainable Urban Development in Germany. ISPRS Int. J. Geo-Inf. 2018, 7, 464. [CrossRef]

19. Boys, B.L.; Martin, R.V.; van Donkelaar, A.; MacDonell, R.J.; Hsu, N.C.; Cooper, M.J.; Yantosca, R.M.; Lu, Z.; Streets, D.G.; Zhang, Q.; et al. Fifteen-Year Global Time Series of Satellite-Derived Fine Particulate Matter. Environ. Sci. Technol. 2014, 48, 11109-11118. [CrossRef]

20. Kanji, R.; Agrawal, R. Building a society conducive to the use of corporate social responsibility as a tool to develop disaster resilience with sustainable development as the goal: An interpretive structural modelling approach in the Indian context. Asian J. Sustain. Soc. Responsib. 2019, 4, 5. [CrossRef]

21. Geng, G.; Zhang, Q.; Martin, R.V.; van Donkelaar, A.; Huo, H.; Che, H.; Lin, J.; He, K. Estimating long-term PM2.5 concentrations in China using satellite-based aerosol optical depth and a chemical transport model. Remote Sens. Environ. 2015, 166, 262-270. [CrossRef]

22. van Donkelaar, A.; Martin, R.V.; Brauer, M.; Hsu, N.C.; Kahn, R.A.; Levy, R.C.; Lyapustin, A.; Sayer, A.M.; Winker, D.M. Global Estimates of Fine Particulate Matter using a Combined Geophysical-Statistical Method with Information from Satellites, Models, and Monitors. Environ. Sci. Technol. 2016, 50, 3762-3772. [CrossRef]

23. Mochizuki, J.; Vitoontus, S.; Wickramarachchi, B.; Hochrainer-Stigler, S.; Williges, K.; Mechler, R.; Sovann, R. Operationalizing Iterative Risk Management under Limited Information: Fiscal and Economic Risks Due to Natural Disasters in Cambodia. Int. J. Disaster Risk Sci. 2015, 6, 321-334. [CrossRef]

24. Cui, H.; Chen, W.; Dai, W.; Liu, H.; Wang, X.; He, K. Source apportionment of PM2.5 in Guangzhou combining observation data analysis and chemical transport model simulation. Atmos. Environ. 2015, 116, $262-271$. [CrossRef]

25. Lin, C.; Li, Y.; Lau, A.K.H.; Deng, X.; Tse, T.K.T.; Fung, J.C.H.; Li, C.; Li, Z.; Lu, X.; Zhang, X.; et al. Estimation of long-term population exposure to PM2.5 for dense urban areas using 1-km MODIS data. Remote Sens. Environ. 2016, 179, 13-22. [CrossRef]

26. Gabbe, C.J.; Oxlaj, E.; Wang, J. Residential development and near-roadway air pollution: Assessing risk and mitigation in San Jose, California. J. Transp. Health 2019, 13, 78-89. [CrossRef]

27. Takano, A.P.C.; Justo, L.T.; Dos Santos, N.V.; Marquezini, M.V.; de Andre, P.A.; da Rocha, F.M.M.; Pasqualucci, C.A.; Barrozo, L.V.; Singer, J.M.; De Andre, C.D.S.; et al. Pleural anthracosis as an indicator of lifetime exposure to urban air pollution: An autopsy-based study in Sao Paulo. Environ. Res. 2019, 173, 23-32. [CrossRef]

28. Firoiu, D.; Ionescu, G.H.; Băndoi, A.; Florea, N.M.; Jianu, E. Achieving Sustainable Development Goals (SDG): Implementation of the 2030 Agenda in Romania. Sustainability 2019, 11, 2156. [CrossRef]

29. Chen, Y.-L.; Tao, T.-H.; Ding, P. Spatial-temporal distribution characteristics of air quality in the urban agglomeration of the yangtze river delta. Resour. Environ. Yangtze Basin 2017, 26, 687-697.

30. Wu, M.; Peng, H.; Fan, S.; Wu, D. Distribution characteristics of regional air quality in the pearl river delta. Environ. Sci. Technol. 2015, 38, 77-82.

31. Breuer, A.; Janetschek, H.; Malerba, D. Translating Sustainable Development Goal (SDG) Interdependencies into Policy Advice. Sustainability 2019, 11, 2092. [CrossRef]

32. Krellenberg, K.; Bergsträßer, H.; Bykova, D.; Kress, N.; Tyndall, K. Urban Sustainability Strategies Guided by the SDGs -A Tale of Four Cities. Sustainability 2019, 11, 1116. [CrossRef]

33. Moonchai, S.; Rakpuang, W. A New Approach to Improve Accuracy of Grey Model GMC(1,n)in Time Series Prediction. Model. Simul. Eng. 2015, 2015, 1-10. [CrossRef]

34. Zeng, B.; Luo, C.; Liu, S.; Bai, Y.; Li, C. Development of an optimization method for the GM(1,N) model. Eng. Appl. Artif. Intell. 2016, 55, 353-362. [CrossRef]

35. Pao, H.-T.; Fu, H.-C.; Tseng, C.-L. Forecasting of $\mathrm{CO}_{2}$ emissions, energy consumption and economic growth in China using an improved grey model. Energy 2012, 40, 400-409. [CrossRef] 
36. Cheng-Ping, Z.; Chuan, L.; Hai-wei, G. Research on Hydrology Time Series Prediction Based on Grey Theory and [epsilon]-Support Vector Regression. In Proceedings of the 2011 International Conference on Computer Distributed Control and Intelligent Environmental Monitoring, Changsha, China, 19-20 February 2011; pp. 1673-1676.

37. Şahin, U. Forecasting of Turkey's greenhouse gas emissions using linear and nonlinear rolling metabolic grey model based on optimization. J. Clean. Prod. 2019, 239, 118079. [CrossRef]

38. Wang, L.; Xie, Y.; Wang, X.; Xu, J.; Zhang, H.; Yu, J.; Sun, Q.; Zhao, Z. Meteorological sequence prediction based on multivariate space-time auto regression model and fractional calculus grey model. Chaos Solitons Fractals 2019, 128, 203-209. [CrossRef]

39. Kayacan, E.; Ulutas, B.; Kaynak, O. Grey system theory-based models in time series prediction. Expert Syst. Appl. 2010, 37, 1784-1789. [CrossRef]

(C) 2019 by the authors. Licensee MDPI, Basel, Switzerland. This article is an open access article distributed under the terms and conditions of the Creative Commons Attribution (CC BY) license (http://creativecommons.org/licenses/by/4.0/). 